\title{
Binet Staging System
}

National Cancer Institute

\section{Source}

National Cancer Institute. Binet Staging System. NCI Thesaurus. Code C20114.

A staging system for Chronic Lymphocytic Leukemia; it is based upon the presence or absence of anemia and/or thrombocytopenia, and involvement of lymphoid tissues, including splenic lymphoid tissue. 